\title{
The Development of Basic Gymnastic Teaching Materials with Hybrid Learning Model Based on KKNI
}

\author{
Indra Darma Sitepu ${ }^{1}$, M. Faisal A. Nasution ${ }^{2}$, Ibrahim ${ }^{3}$ \\ \{pieblux@gmail.com ${ }^{1}$ \} \\ Department of Sports Sciences, Faculty of Sports Sciences, Universitas Negeri Medan, Medan, \\ North Sumatra, Indonesia ${ }^{123}$
}

\begin{abstract}
Innovation in education is currently growing, where the use of communication and information technology in education is a challenge for educators in the teaching and learning process. This study aims to produce teaching materials for the basic gymnastic model of hybrid learning namely combining teaching materials in print out and elearning. It is expected that the use of communication and information technology in the learning process through this product can ultimately solve the problem of the lack of learning resources for basic gymnastic courses, and the improvement for the quality of teaching and learning process for PKO students in the Faculty of Sport Science. The implications of this product help the lecturers to carry out learning in accordance with the demands of the KKNI curriculum. This study uses a research and development (R \& D) approach that begins with a needs analysis. The results of this analysis became the basis for the preparation of teaching materials for basic gymnastics with hybrid learning models based on KKNI.
\end{abstract}

Keywords: Teaching Materials, Hybrid Learning, Gymnastic, KKNI.

\section{Introduction}

The use of communication and information technology in the field of education is an effort to improve the quality of the learning process through various studies on the process of interaction of students with educators and learning resources in a learning environment. In the current learning process, there is a tendency for: a) to shift education from teacher-centered learning systems to student centered, b) to grow and to become more open or distance education (Steep, 2002: 165). c) the more choices of learning resources available (Riyana, 2010: 42). Rosenberg (2001: 8) added that there were three shifts in the learning process due to the development of communication technology, namely: a) shifting from classrooms to anywhere and anytime, b) shifting from paper to online, and c) shifting physical facilities to network facilities. With the development of information technology, educators can provide services or facilitate without having to deal directly with students, as well as students can obtain information in a wide scope from various sources through virtual space using the internet.

The enactment of the IQF curriculum has provided guidelines for universities to prepare their graduates to have competencies recognized by the labor market. With the existence of the IQF will change the perspective of one's competence, no longer just a diploma but also refers 
to the nationally agreed qualification framework as a basis for recognition of the results of a broadly accountable and transparent education of a person. Therefore, it needs to be anticipated by reviewing the learning strategies in preparing a learning activity, especially relevant teaching materials according to the needs of stakeholders in the labor market while keeping in mind that the material developed must be adapted to the development of students, abilities, interests and needs. the whole supports the achievement of graduate competencies.

Conditions in the field based on the results of observations and interviews with the lecturers of Basic Gymnastics courses found several things, namely: 1) there are limitations to supporting books for courses, 2) students find it difficult to visualize movement techniques in gymnastics because they have to wait for the face to face process first, 3) The lecturer does not have a Semester Learning Plan for basic KKNI based gymnastics courses. This means that the lecturer teaches not yet fully based on the KKNI curriculum demands with material that is not sequential and combined with the lecturer experience about the material in accordance with the lecturer's memory so that the opportunity for giving material coverage becomes too broad, and students are less active because they are only waiting for material from face-to-face lectures. Whereas this basic gymnastics course has links with other training courses such as coaching methodology, physical training methods, techniques \& tactics training methods, measurement tests and coaching clinic. It is also complicated by the inequality of perception among lecturers, so that the material coverage that students should get in the learning process can vary and certainly makes it difficult for students to take advanced gymnastics courses in Sports Coaching Education.

This condition is of concern, and must be corrected immediately so that the graduates' achievements in the course are clear and achievable, thereby contributing to the achievement of the competence of study program graduates. Students will be greatly helped by the existence of course teaching materials from the lecturer so that he can prepare himself before, when the meeting or after the lecture takes place as a material for self-evaluation. As for lecturers, this teaching material can be a guide for teaching and motivating lecturers to develop their abilities related to the presentation of learning.

\section{Manuscript preparation}

\subsection{Concept of development research}

Development research or known as research and development (R \& D) is a research that produces an effective product to solve problems, starting with needs analysis, product development, and product testing. this research is not used to test theory but to produce a product or perfect an existing product so that it becomes part of problem solving.

According Sugiyono (2008: 297) Development research is research used to produce certain products and test the effectiveness of these products. The ideas obtained from the needs analysis were poured into the concept script to the design of prototypes and through testing stages before the prototype was deemed feasible to be produced into a product that was used in bulk.

Development research gave birth to something new according to the demands of the field of study carried out and obtained from the research process carried out and supported by research data that was systematically collected in accordance with the phasing of the research models 
used such as ADDIE model, Four D model or Plomp model, Borg and Gall Model (Gusril, 2016: 12).

Development research using models from Borg and Gall (in munawwaroh, 2012: 2-3) includes ten activities, namely 1) preliminary study, 2) research planning, 3) initial product development, 4) initial (limited) field trials, 5) revision of limited field test results, 6) wider field tests, 7) revision of field test results, 8) feasibility tests, 9) revision of feasibility test results, 10) dissemination and dissemination of final products.

The existence of a problem can be a way for the emergence of new ideas which if packaged using a scientific approach will generate a solution as a solution to an existing problem. Problems can arise because there is a cause and this certainly encourages the emergence of an effect, it can be a series of repeated repetitions if a solution is not immediately found to overcome it.

A variety of products can be produced from development research, depending on the topic studied to be developed into something new and the target of the user of the product. The form of the products produced does not have to be in the form of hardware but can also be in the form of software ) In the world of education products from the development research that are often found include learning devices and learning models.

Learning tools and models are produced according to the level of need for problem solving encountered by researchers in learning. For example a learning device that contains the needs of the learning process will be related to planning, implementing, and evaluating learning, can play a role as a guide for lecturers in carrying out their duties in teaching.

\subsection{Hybrid learning}

Hybrid Learning or often called Blended learning has several definitions, but in general hybrid learning is known as learning that combines online learning with face-to-face learning (face to face $=$ f2f) (Akkoyunlu \& Soylu, 2008: 183; Garrison \& Kanuka, 2004 : 96-97; Baum, 2013 and Garrison \& Vaughan, 2008: 6). Today the term hybrid has become popular, so more and more combinations are referred to as hybrid learning. In the research methodology, the term mixing is used to show a combination of quantitative and qualitative research. There is also a mention in learning is an eclectic approach, which is combining various approaches to learning

However, the notion of blended learning based learning is learning that combines learning delivery strategies using face-to-face activities, computer-based learning (offline), and online computers (internet and mobile learning).

Hybrid learning based learning developed around 2000 and is now widely used in North America, England, Australia, universities and the world of training. Through hybrid learning all learning resources that can facilitate learning for people who learn are developed. Hybrid learning can combine face-to-face learning with computer-based learning. That is, learning with a learning technology approach with a combination of face-to-face learning resources with instructors and those contained in computer media, cellular phones, satellite television channels, video conferencing, and other electronic media. Students and instructors / facilitators work together to improve the quality of learning. The main objective of hybrid learning is to provide opportunities for various student characteristics to enable independent, sustainable and lifelong learning to occur, so that learning will be more effective, more efficient, and more interesting.

Hybrid learning based learning is the best choice to increase effectiveness, efficiency, and greater attraction in interacting between humans in diverse learning environments. Blended 
learning offers learning opportunities to be both together and separately, as well as at the same time and differently.

\subsection{Gymnastic}

Hidayat (2004: 1) said: "gymnastics is a body exercise that is chosen and constructed intentionally, done consciously and planned, systematically arranged with the aim of increasing physical fitness, developing skills and instilling mental spiritual values". DISPORA (2004: 3) divides gymnastics sports organized by FIG (Federation International de Gymnastigue) into 6 groups, namely; 1. Artistic Gymnastics, 2. Rhythmic Sportif Gymnastics, 3. Acrobatic Gymnastics, 4. Aerobic Gymnastics, 5. Trampoline Gymnastics, 6. General Gymnastics.

DISPORA (2004: 3) proposes "artistic gymnastics, which is a gymnastics that combines tumbling and acrobatic aspects to get artistic effects from movements performed on the following tools: 1. Floors, 2. Vault , 3. Pommel Horse, 4. Paralel Bars, 5. Horizontal Bar, 6. Still Rings.

Based on the description above it can be concluded that gymnastics is a body exercise that is carried out consciously and planned that is carried out on the division of gymnastic groups such as; 1. Artistic Gymnastics, 2. Rhythmic Sportif Gymnastics, 3. Acrobatic Gymnastics, 4. Aerobic Gymnastics, 5. Trampoline Gymnastics, 6. General Gymnastics.

According to the Ministry of National Education (2013: 173) floor gymnastics is one of the clumps of gymnastics. In accordance with the term floor, the movements / forms of learning are carried out on the floor. So, the floor or mattress is the tool used. Floor gymnastics is also called free learning. Because it does not use objects or other tools when running it. The purpose of doing floor gymnastics in addition to improving the ability to do the forms of floor gymnastics movement itself is also a learning of the ability to do gymnastic movements with tools.

Floor gymnastics has mental and social benefits, students are required to think for themselves about developing their skills. For this reason, students must be able to use their thinking skills creatively through solving motion problems. Thus students will develop their mental abilities. Fitness or physical fitness is very important for human survival, where physical fitness includes and affects all aspects of the body. A person's physical fitness is the most important element in life even more so for someone who is elderly. Because all physical activities carried out by each individual will not be separated from the physical fitness conditions. So in this case physical fitness is something that is absolutely owned by every human being who wishes to live a healthy and fresh life.

Gymnastics theory and movement have relationships with other sciences, such as anatomy, physiology, biomechanics of nutrition, psychology, measurement tests and history. The purpose of studying basic gymnastics courses is that students as prospective educators and trainers need to have knowledge related to theoretical studies and implementation in various basic knowledge of gymnastics.

\subsection{Development of teaching materials}

Learning is interpreted as a process of behavior change as a result of the interaction between individuals and their environment. That behavior includes aspects of knowledge, skills and attitudes (Husdarta, 2013: 4). Therefore learning can be said to add, expand, and deepen 
knowledge, values, attitudes, and skills. The implementation of learning in universities is an implementation of what has been planned in the learning program prepared by the lecturer.

Teaching materials are all forms of materials used to assist teachers / instructors in carrying out teaching and learning activities (Majid, 2016: 173). More detailed about the definition of instructional materials proposed by Yaumi that learning materials or teaching materials are a set of materials that are systematically arranged for learning needs sourced from printed materials, visual aids, audio, video, multimedia, animation, computer and networking (2013: 272) .

Lecturers compile teaching materials that contain information and knowledge that can be used by students to carry out the learning process in an effort to achieve specific competencies. Majid (2016: 174) suggests that a teaching material includes at least: 1) learning instructions, 2) competencies to be achieved, 3) supporting information, 4) exercises, 5) work instructions, can be in the form of worksheets, 6) evaluation.

Teaching materials are used as a tool to achieve learning competencies, therefore in its preparation must be guided by the learning outcomes of graduates of courses that contribute to the profile of study program graduates. as well as in the selection of teaching materials, the characteristics of the students are adjusted so that all teaching materials can be conveyed to students.

The instructional material according to Dick \& Carey (2009: 230) is containing content that is written, mediated, or facilitated by instructors used by students to achieve goals and include information about students who will be used to guide progress. Furthermore Dick and Carrey (1996: 228) suggested that the development of teaching materials needed to pay attention to the following matters, namely: 1) paying attention to the desired learning motivation, 2) the suitability of the material given, 3) following a correct sequence, 4) contains the information needed, 5) the existence of practical training, 6) can provide feedback, 7) available tests in accordance with the material provided, 8) available instructions for follow-up or general progress of learning, 9) instructions available to students for the stage the activity stage, 10) can be remembered and transferred.

Suhartati (in yaumi, 2013: 274) stated that the position of teaching materials is 1) can help in individual learning, 2) provide flexibility in the presentation of short-term and long-term learning, 3) systematic design of teaching materials that have a great influence on the development of human resources individuals, 4) facilitate the teaching and learning process with a system approach, 5) facilitate learning because it is designed on the basis of knowledge about how humans are.

Related to basic gymnastic teaching materials, Bompa (2009: 3) identifies the main elements in gymnastics, namely at the center of training theory that a structured training system is built on the scope of exercise activities that target the physiological, psychological, and specification characteristics of sports and athlete performance.

\subsection{KKNI curriculum}

Mandate Law number 12 of 2012 Article 29 paragraph 1 states that the Indonesian National Qualification Framework (KKNI) is a level of learning achievement that equates the outcomes of formal, non-formal, informal, or work experience in the framework of recognition of work competencies in accordance with the structure of work in various sectors. The derivative of the law is stated in the Republic of Indonesia Presidential Regulation number 8 of 2012 so that currently the IQF is used as a basic reference in determining the competence of graduates of academic education, vocational education and professional education. 
Determination of the qualification level must be based on Learning Outcomes (CP) because through learning outcomes can be described one's skills and career. Learning outcomes are what is known, understood and can be done by someone after completing the learning process (Kemendikbud, 2014: 3).

Giving recognition to work competencies based on one's learning achievement obtained from various paths (formal, non-formal education, work experience, or increased professionalism) is structured into a gap framework in accordance with the structure of work in various sectors so that the world of work recognizes a person's competence. In the KKNI there are nine levels that have descriptions of learning outcomes in accordance with their respective qualifications. Learning outcomes obtained from various channels, in this IQF will be equalized with the level of job expertise (operator, technician / analyst, expert) so that someone who has taken competency improvement paths will be known at what level according to the IQF.

Qualification descriptions at each level of the IQF are expressed as CP covering aspects of national identity building, mastery of science and technology, ability to be able to do quality work, as well as one's authority and obligations according to the level of qualifications (Kemendikbud, 2014: 5). Through this description a formulation of learning outcomes is formulated, known as the four elements of the IQF description, namely 1) attitudes and values, 2) work ability, 3) knowledge mastery, 4) authority and responsibility.

Description of CP KKNI is a reference to formulate the formulation of $\mathrm{CP}$ for university graduates. The formulation is stated in 3 elements (Kemendikbud, 2014: 6) as follows:

a) The attitude element in CP is the attitude possessed by college graduates

b) The element of knowledge has the same meaning as the element of mastery of knowledge from CP KKNI, which must be mastered by graduates of certain study programs

c) Elements of skills are a combination of elements of work ability and elements of authority and responsibility of the description of the IQ KKNI

d) Elements of special skills characterize the ability of study program graduates according to certain fields of science / expertise, while general skills characterize the ability of graduates according to the level and type of education program not dependent on the field of study

The PKO department aims to produce competent graduates as trainers, teachers and sports managers with character. Competence must certainly include 3 elements of learning achievement of college graduates, so that graduates who are graduates of higher education if adjusted to the level of work ability in the description of the IQF are at level 6, namely at least having the ability to apply, study, design, utilize science and technology and solve problems .

Medan State University applies the IQF curriculum in lectures as a step to answer the demands of the times for the needs of competent graduates who are recognized for their level of expertise in the job market. Therefore, the PKO department must be able to prepare its graduates to have competencies recognized by the labor market so that the implementation of the IQF curriculum is carried out through the learning of courses, which is carried out since the planning, implementation and evaluation process. 


\section{Methods}

This research was conducted for 4 months at the Unimed FIK Sports Coaching Education Department. This research uses research \& development (R \& D) method. The steps that have been modified include: needs analysis, formulation of objectives, drafting of scripts, evaluation and revision I, test I, revision II, trial II, evaluation, manuscripts ready for production, final production.

\subsection{Sample and population}

The population and sample of this study came from the first semester students majoring in sports coaching education who took basic gymnastics courses, while sampling used random sampling techniques

\subsection{Data collection and analysis technique}

Research data was collected through observation, interviews, and document studies. Document study is carried out to collect data contained in the relevant documents as material for the preparation of teaching materials. The data analysis technique used is quantitative descriptive analysis with percentages.

\section{Results and discussion}

The results of the needs analysis are carried out through questionnaires, structured interviews and document studies for students, lecturers, trainers and stakeholders. The results of the questionnaire on the level of teaching material needs distributed to 25 student respondents, if it was concluded that students needed help to overcome difficulties in obtaining subject learning textbooks $(80 \%)$, knowing the limitations of subject learning materials $(72 \%)$, knowing the learning achievement of the eye college (92\%), and students need clarity of instructional instructions and assignment of courses (92\%).

The researcher also conducts structured interviews to the lecturers of basic gymnastic courses in the PKO department to obtain information input related to the learning process of the basic subjects of sports coaching science. The results of a small group trial involving a sample of 15 people provided input information for the implementation of stage II revision before proceeding to the large group trial stage.

From the assessment questionnaire, it was found that at this stage the draft teaching materials were able to meet several criteria for teaching material needs for students, although there were still some inputs that needed attention by researchers to improve the draft teaching materials before testing on large groups, among others: assignment obscurity (20\%), noncompliance with font size $(25 \%)$, unattractive content layout $(20 \%)$, unattractive teaching material design (14\%).

The results of student assessment of the draft teaching materials used in large group trials showed that the draft teaching materials had met the criteria of a teaching material that was ready for use in the learning process.

Large group trials involved a sample of 50 people. The implementation of large group trials resulted in several notes on product excellence, including: (a) facilitating lecturers in 
providing material understanding to students, (b) students know the learning achievement of courses, (c) teach students about the concept of basic gymnastics, (d) learning materials are arranged with the concept of interconnectedness between materials, (e) learning Basic gymnastics becomes more attractive with the increasing active participation of students, (f) helping to grow the character of students through the assignments given.

The results of large group trials found that teaching material products were able to increase student participation in learning because they already had organized learning resources. But in this study found some limitations including: (1) Field trials in this study only involved limited and random samples, (2) The amount of product contribution to learning was still influenced by the readiness of lecturers and the learning model used, (3) Material description instructional materials related to advanced course material from a series of coaching subjects in sports coaching education.

\section{Conclusion}

Based on the results of the field trials and the results of the researchers 'discussion, it can be concluded that: (1) The developed teaching materials increase the students' participation in learning in the basic gymnastics courses, (2) the research carried out produces basic gymnastic teaching materials for use in gymnastics lectures. basic. 


\section{References}

[1] Bompa, Tudor O., Haff , G.Gregory.: Periodization. Theory and Methodology of Training. Fifth Edition. Champaign. Human Kinetics, (2009)

[2] Dirbelmawa.: Panduan Penyusunan Capaian Pembelajaran Program Studi. Kemdikbud, Jakarta (2014)

[3] Dirjenbelmawa.: Kerangka Kualifikasi Nasional Indonesi. Kemristekdikti, Jakarta (2015)

[4] Gusril.: Penelitian Pengembangan Dalam Ilmu Keolahragaan. Kencana, Jakarta (2016)

[5] Http://bahanajarpendidikan.blogspot.co.id/2016/07/pengertian-bahan-ajar-serta-jenis-jenis.html

[6] Husdarta.: Belajar dan Pembelajaran: pendidikan Jasmani dan Kesehatan. CV.Alfabeta, Bandung: (2013)

[7] Mahmudi Sholeh.: Olahraga Pilihan Senam. DEPDIKBUD, Surakarta (1992)

[8] Majid, Abdul.: Perencanaan Pembelajaran. Bandung: PT Rosda (2016)

[9]Munawwaroh,Isniatun.:http://staff.uny.ac.id/sites/default/files/PENELITIAN\%20PENGEMBANG AN.pdf

[10] Yaumi, Muhammad.: Desain Pembelajaran. Kencana, Jakarta (2013) 